\title{
Infusion Media. When? What and How Much?
}

\section{Bocharov SN*, Bocharova YuS, Mankov AV, Golub IE and Sorokina LV}

Irkutsk State Medical University, Irkutsk, Russia

*Corresponding Author: Bocharov SN, Irkutsk State Medical University, Irkutsk, Russia.
Received: October 20, 2021

Published: December 22, 2021

(C) All rights are reserved by Bocharov SN., et al.

\begin{abstract}
Topicality: The key link in the perioperative period of treatment of patients with various pathologies and, especially, all kinds of shock states, is infusion-transfusion therapy, the effectiveness of which depends on the functional state of transcapillary metabolism, determined by the value of oncotic plasma pressure - a derivative of the concentration of Total Protein, and not albumin!.

The traditional method of correction of hypovolemia/blood loss of any genesis and any volume remains hypervolemic hemodilution, accompanied by excessive administration of crystalloid(Na containing) and artificial colloidal solutions, at the same time, neither the sector of their stay is taken into account, nor the volemic coefficient, nor the features of their clinical manifestation are taken into account and ted.
\end{abstract}

Work: Development of a program for replenishing hypovolemia/hemorrhage, based on the principle of normalization of transcapillary metabolism and the justification of infusion solutions used to correct it.

Material and Methods: Based on the analysis of infusion media used in the 30-year period of perioperative treatment of surgical and trauma patients, development and justification of the principles of the program of replenishment of blood loss/hypovolemia, based on the normalization of transcapillary metabolism. Criteria for the effectiveness of treatment, an algorithm for correcting blood loss/hypovolemia are formulated and substantiated. According to the results of a comparative analyzes obtained when performing hemihepathecomy confirmed the high clinical effectiveness of the method of blood loss correction based on the normalization of transcapillary metabolism. This method was used and improved by techniques: preoperative blood procurement and postoperative return of drainage blood in the 20-year period of treatment of trauma patients.

Conclusion: According to the results of the performed studies, high clinical efficacy has been proven and undeniable advantage, which was as follows: patients who underwent hemihepatectomy were discharged with recovery, and 20 years of experience in the practical use of this program in trauma patients confirmed the absolute effectiveness of and security.

Keywords: Total Protein; Albumin; Oncotic Pressure Hypervolemia; Transcapillary Metabolism; Infusion Media

\section{Topicality}

The traditional way of correcting hypovolemia/blood loss of any genesis and any volume remains hypervolemic hemodilution, based on excessive administration of crystalloid (Na containing) and artificial colloidal solutions. The principles of blood loss correction are:

- Replenishment of the volume of circulating blood (BCC), which is provided by crystalloid and colloidal (plasma substitutes) solutions.
- Restoration of oxygen-transport function is performed by transfusion of erythrocyte containing solutions, usually erythrocyte mass (E/M).

- Restoration of lost coagulation factors is associated with the use of freshly frozen plasma (NWF).

At the same time, the ratio of the volumes used infusion solutions to the volume of blood loss is traditionally recommended as 3-2-1, in accordance with the above principles: 3 are crystalloid and 
colloidal solutions, 2-erythromassa, and 1 - freshly frozen plasma, but there are others blood loss replacement programs: isovolemic hemodilution, acute hemodilution, etc. [1,4,8,12,16,20].

All known domestic and foreign programs have their own similar features: the sectors of their stay, volemic coefficients (VC) of infusion media, features of their clinical manifestation are not taken into account.

So, regardless of the volume of hemorrhage, the volume of infusion any corrective Program, at least exceeds the volume of blood loss in 3 - 4 Times and first of all, this is due to the use of crystalloid $\mathrm{Na}$ - containing infusion media. These same solutions have their own about peculiarity - ability their StaySee also in the vascular only 30 minutes, and then $70 \%$ infused the volume moves into the interstitial space, dragging water with it to equalize $\mathrm{Na}$ - ion concentrations, forming swelling pоsлEdnego, Which one, originally, will be of a hidden nature, and with their volumetric use - with the manifestation of "multiple organ failure syndrome" [1,3,13$16,19,24,28]$.

This is especially evident in cambustiological patients, where, it would seem, there is no blood loss, but there is a loss of plasma, which is accompanied by a decrease in oncotic pressure with a violation of transcapillary exchange (MSW) in the form of a predominance of filtration processes. Cambustiologists, from the first day of treatment in order to correct hypovolems, perform a v/vinnaya volume infusion with balanced crystalloid solutions, which further reduces the concentration of total protein, including albumin, more significantly damaging TCR. The latter, in turn, is accompanied by edema of the interstitial space with clinical manifestations of RDS of the lungs, paresis of the gastrointestinal tract and other manifestations of SPON, which, initially, are hidden, and then manifesting $[1,3,8-10,14,20,21]$.

On the other hand, the excessive use of crystalloid and colloidal solutions that do not contain either protein or hemocoagulation components is always accompanied by a natural decrease in their concentrations, against which the use of volumetric infusion therapy will more significantly damage the functional state of both TCR and the hemostasis/coagulation system [1,6,8,17,19,22,23].

These circumstances determined the purpose of this work, which is to develop a program for replenishing hypovolemia/hemorrhage based on the principle of normalization of transcapillary metabolism and the justification of infusion solutions used to correct it.
In connection with the goal, it was necessary to solve certain tasks:

- Evaluate the characteristics of infusion media from the standpoints: their volemic coefficient (VC); time and sector of stay in the body; clinical effects.

- Determine the principles of the program of replenishment of hypovolemia/blood loss.

- Identify criteria for aid effectiveness.

- Develop an algorithm for the program of correction of hypovolemia/hemorrhage.

- To conduct a comparative analysis of the effectiveness of the developed and traditional programs, on the example of replenishment of blood loss.

- According to the results of a comparative analysis, to determine the advantages and disadvantages of the developed method of replenishing hypovolemia/hemorrhage.

\section{Material and Discussion}

Features infusion media

Crystalloid Na containing balanced and unbalanced solutions were developed to replenish and correct electrolyte disorders of the interstitial space [16]. All have in their composition the main osmotically active component - the $\mathrm{Na}$, the same volemic coefficient $(\mathrm{VK})=0.3$. Stay in the vascular bed only 30 minutes, after which only $30 \%$ of this solution remains in the vascular bed (VK $=0.3$ ), and $70 \%$ of the solution moves into the interstitial space, dragging water with it (isoosmolarity law or Gibbs-Donnan equilibrium) to equalize the concentrations of Na cations, which determines the emerging edema of the interstitial space, which, initially, will be hidden, and with the continued use of crystalloid Na containing infusion media, will develop into manifesting the syndrome of "multiorgan" insufficiency" (SPON) or "capillary leakage" Crystalloid solutions determine osmotic pressure or osmolarity. Norm $=280-300 \mathrm{mmol} / \mathrm{l}$.

$5 \%$ glucose solution also belongs to the group of crystalloid solutions, but is absolutely devoid of cations $\mathrm{Na}, \mathrm{VC}=0.3$, stays in the vascular bed for the same 30 minutes, is metabolized to form water and $\mathrm{CO}_{2}$, water is distributed in the interstitial space and inside the cellular sector, and carbon dioxide is removed through the lungs. Essentially, it is pure water $[9,10,13,16,18,22,28-32]$.

Artificial colloids are represented by dextrans, hydroxyethyl starches and gelatins, which in their composition do not have a 
protein substrate, have a molecular weight (MM) of 10 thousand Dalton (Da) and more, which determines their ability to stay only in the vascular bed. The clinical effect is to restore and stabilize the volume of circulating blood (BCC), and their duration of action is from 4 to 22 hours. At the end of the action time, these solutions are metabolized, are excreted by the kidneys, and the clinical effect stops. In the group of dextrans, Polyglyukin is most often used, having VK = 1.45 and Reopoliglyukin, with VK - 1.7. And among starch derivatives - $6 \%$ solution of Refortan, $\mathrm{VK}=1$ and Voluven, with $\mathrm{VK}=1$. The features of dextrans and starch derivatives include their ability to damage the vascular-platelet and coagulation links of the hemostasis system, which must be taken into account when using solutions of these groups and not exceed their daily dosage. $4 \%$ solution of succinated gelatin - Gelofuzin, has VK $=1$, the time spent in the vascular bed is only 4 hours, but its daily dosage is 200 $\mathrm{ml} / \mathrm{kg}$ ! Unlike dextrans and hydroxyethyl starch, it is isooncotic, isoosmotic, does not inhibit the functional state of the hemostasis system, but can show severe allergic reactions. Artificial dextrans determine the amount of colloidal pressure. The clinical effect of these solutions is determined by their volemic coefficient (VK) and the time of stay in the vascular bed [1-11,25,26,29,30,33].

Natural colloidal solutions are Freshly frozen Plasma (NWS), and Albumin solutions.

The composition of NWF is $55-65 \%$ albumin $+35-45 \%$ globulin $+1 \%$ fibrinogen. Clinical effects: a source of plasma coagulation factors, increases oncotic blood pressure; normalizes the functional state of transcapillary metabolism; prevents swelling of the interstitial space and damage to the microcirculation system of the lungs; prevents the development of multiple organ failure syndrome; forms a tolerant strategy for adapting the patient's body; provides functional functionality stability of the body.

Albumin is a monodisperst colloid made from the blood of donor plasma, regardless of blood group. Hemocorrector, disaggregant, metabolic adsorbent. It has a volemic coefficient of 1.47. It contributes to the normalization of oncotic blood pressure, functional stability of transcapillary exchange, fluid retention in the vascular bed and its additional movement from the interstitial space to the vascular bed. Natural colloids determine the amount of oncotic pressure, which is calculated by the formula:

Total Protein $\mathrm{x} 0.33$ Norm $=21-25 \mathrm{mmHg}$.

The duration of natural colloidal solutions up to 19 days [8$11,27,34]$
The erythrocyte mass is designed to ensure and maintain the normal oxygen-transport function of the blood, is only in the vascular sector, has a $\mathrm{VC}=0.8$, since after its transfusion, $18 \%$ are sequestered in the spleen, liver, and up to $2 \%$ of red blood cells are destroyed. A feature of this environment is the implementation of metabolic processes with the predominant formation of not ATP (adenosine triphosphoric acid), but 2-3 DFG (diphosphoglycerate), responsible for the affinity of hemoglobin and oxygen a, when storing donor blood, its concentration decreases, and after transfusion it is restored within 8 to 16 hours, depending on the shelf life of donor blood. The clinical effectiveness of their use is determined by the values of hemoglobin and hematocrit number [1,4,7,9-11,17].

Principles of the program of replenishment of blood loss/hypovolemia, based on the normalization of transcapillary exchange

- Correction of transcapillary exchange is based on maintaining normal oncotic pressure with freshly frozen plasma and $5 \%$ to $10 \%$ with albumin solution, under the control of the concentration of Total Blood Protein, but not albumin.

- Replenishment of the BCC is provided by the use of a 5\% glucose solution and artificial (not having a natural protein) colloidal solutions in compliance with their daily dosages, under the control of blood pressure, CVD (if possible), diuresis.

- Restoration of coagulation factors of coagulation is provided by the use of NWF, under the control of the concentration of fibrinogen and VSK.

- Normalization of oxygen-transport function is provided by the use of erythromass, under laboratory control of the values: $\mathrm{Hb}, \mathrm{Ht}, \mathrm{AD}, \mathrm{CVD}$ (if possible) and $\mathrm{SPO}_{2}$

- Crystalloid (Na containing) solutions from the program are completely excluded and can be used only for absolute indications under laboratory control of the concentration of ions $\mathrm{Na}$ [1-10].

\section{Clinical criteria for the effectiveness of care}

- The concentration of hemoglobin should not be lower than $\mathrm{Hb}>90 \mathrm{~g} / \mathrm{l}$. This is its minimum concentration, which is able to ensure the delivery of oxygen that meets the needs of the patient's body.

- The value of the hematocrit number is not lower than (Ht) $\geq$ $35-30 \%$, will confirm a sufficient concentration of the oxygen carrier, which will ensure the delivery of oxygen in accordance with its needs of the patient's body. 
- $\quad$ The level of central venous pressure (CVD) is not less than +4 $\mathrm{cm}$. guarantees compliance with the BCC capacity of the vascular bed, which prevents the centralization of blood circulation (spasm of peripheral blood circulation).

- Total protein not lower than $65 \mathrm{~g} / \mathrm{l}$ will maintain effective oncotic pressure, which is necessary to maintain normal transcapillary metabolism, prevent edema of the interstitial space, prevent SPON and functional stability of the body.

- Stabilization of hemodynamics, including average blood pressure not lower than $65 \mathrm{~mm} \mathrm{Hg}$. confirm the adequacy of infusion-transfusion therapy.

- The presence of diuresis in the volume of $30 \mathrm{ml} / \mathrm{h}$, will confirm the effectiveness of therapeutic measures and the absence of centralization of blood circulation.

- The concentration of fibrinogen 1.5 - $3.5 \mathrm{~g} / \mathrm{l}$ and the absence of fibrin degradation products (PDF) will confirm the functional stability of the hemostasis system [1,8-15].

\section{Algorithm of the blood loss correction program}

The total volume of infusion (0.0b.) is the daily requirements (Preoperative waiting time and the time of operation X $40 \mathrm{ml} / \mathrm{kg}$ ) + pathological losses. The calculated criterion for BCC deficiency is Algover's inlex (heart rate/AD systolicheskoe).

The volume of blood loss up to $15 \%$ BCC

The use of blood components is not indicated.

In order to intraoperatively reduce the volume of blood loss an hour before the operation, the patient is injected with a solution of tranexamic acid at the rate of $15 \mathrm{mg} / \mathrm{kg}$ of weight (endogenous proteolysis inhibitor), or a solution of dicinone at a dose of $500 \mathrm{mg}$, (in order to enhance platelet adhesion) on the operating table.

To compensate for preoperative hypovolemia, which is formed in the patient during the period of waiting for surgery and correction of intraoperative hypovolemia, which is formed during the period of the operation, we use in equal volumes of $50 \% 0.0 b$. $5 \%$ glucose solution and $50 \%$ 0.0b. colloidal solution of Voluven or Gelofuzin.

The volume of blood loss is up to $30 \%$ of the BCC

It is necessary to use a protein substrate to correct oncotic pressure, in order to ensure normal MSW. The total volume of infusion is distributed as follows:
- $35 \%$ 0.0. - A solution of $5 \%$ glucose, to compensate for preoperative hypovolemia.

- $\quad 35 \%$ 0.0. - Artificial Colloidal solution of Voluven or Gelofusin to maintain BCC.

- $\quad 60 \%$ 0.0. - A natural colloidal solution, preferably SZP, to preserve oncotic blood pressure, optimize MSW, preserve BCC, ensure its compliance with the capacity of the vascular bed, prevent edema of the interstitial space and exclude the development of SPON.

The use of prednisolone solution at a dose of $5 \mathrm{mg} / \mathrm{kg}$ of mass is necessary to ensure the stability of cell membranes.

The volume of blood loss $\geq 40 \%$ of the BCC

Requires full-capacity infusion therapy using infusion media and whole blood components. The total volume of infusion will be distributed as follows:

- $27 \% 0.0$ is reimbursed with a solution of $5 \%$ glucose to compensate for preoperative hypovolemia.

- $\quad 27 \% 0.0 b-$ A solution of Voluven or Gelofusin to preserve the BCC and its compliance with the capacity of the vascular bed.

- $40 \%$ 0.0. Is covered by NWF to maintain normal oncotic blood pressure, optimize MSW, preserve BCC, ensure its compliance with the capacity of the vascular bed, prevent edema of the interstitial space and exclude the development of multiple organ failure syndrome.

- $\quad 30 \% 0.0 b$ - will be erythromass to ensure normal oxygentransport function and ensure the delivery of $\mathrm{O}_{2}$, which will meet its increasing needs.

- The use of prednisolone solution at a dose of $5 \mathrm{mg} / \mathrm{kg}$ mass is necessary to ensure the stability of cell membranes.

- While maintaining the transient function of zh-k-t, the natural method of correction (per-os) of fluid and food ingredients (protein substrate) is the main!!!

\section{Discussion}

Comparative analysis of programs replenishment of hypovolemia/blood loss

This method of replenishing blood loss was developed in 19881989 to perform hemihepatectomy, accompanied by massive hemorrhage, the compensation of which, until this period, was performed in the traditional way - hypervolemic hemodilution, and the mortality rate of this group of patients was $33.3 \%$. 
The clinical efficacy of the new method of replenishing blood loss, based on the normalization of MSW, is characterized by a complete absence of mortality in patients of the main group in whom this method of blood loss correction was used and is further confirmed by the results of some studies illustrated below.

With an initial equal concentration of total blood protein, from the second day of the postoperative period, it became significantly higher in the main group of patients: $56.7 \pm 2.3 \mathrm{~g} / \mathrm{l}$ against 43.9 $\pm 2.8 \mathrm{~g} / \mathrm{l}$ of the comparison group. This was reflected in the value of oncotic pressure (CODE) of blood, which from the second to 5 days of the postoperative period was significantly higher in the main group of patients who used a method of blood loss correction based on the normalization of trankapillary metabolism (Table 1).

\begin{tabular}{|l|c|c|}
\hline \multirow{2}{*}{$\begin{array}{l}\text { Research } \\
\text { time }\end{array}$} & \multicolumn{2}{|c|}{ Patient groups } \\
\cline { 2 - 3 } & $\begin{array}{c}\text { Control group } \\
\text { (n= 18) }\end{array}$ & Basic group $(\mathbf{n}=\mathbf{4 0 )}$ \\
\hline Before surgery & $27,7 \pm 2,4$ & $28,1 \pm 2,7$ \\
\hline 1 day & $20,3 \pm 2,1$ & $20,4 \pm 2,5$ \\
\hline 2 days & $16,8 \pm 1,7^{*}$ & $21,6 \pm 1,9^{*}$ \\
\hline 4 - 5 days & $18,0 \pm 1,8^{*}$ & $23,1 \pm 2,1^{*}$ \\
\hline
\end{tabular}

Table 1: Changes in oncotic pressure ( $\mathrm{N}=18-30 \mathrm{mmHg})$.

* - reliably distinguishing values between groups $(\mathrm{p}<0.05)$.

Effective oncotic blood pressure allowed to maintain adequate MSW and retain fluid in the vascular bed in patients of the main group. Assessing the effectiveness of MSW through the difference between OD and ACS, it was found that in the main group of patients it was more than 0 and testified to the functional stability of MSW (Table 2).

\begin{tabular}{|l|c|c|}
\hline \multirow{2}{*}{ Research time } & \multicolumn{2}{|c|}{ Patient groups } \\
\cline { 2 - 3 } & Control group (n= 18) & $\begin{array}{c}\text { Basic group } \\
\text { (n = 40) }\end{array}$ \\
\hline Before surgery & $8,2 \pm 0,76$ & $8,9 \pm 0,75$ \\
\hline 1 day & $1,7 \pm 0,24$ & $2,5 \pm 0,28$ \\
\hline 2 days & $-0,1 \pm 0,03^{*}$ & $5,1 \pm 0,34^{*}$ \\
\hline 4 - 5 days & $-0,5 \pm 0,02^{*}$ & $4,5 \pm 0,38^{*}$ \\
\hline
\end{tabular}

Table 2: Dynamics of OD/SKD gradient ( $\mathrm{N} \geq 0 \mathrm{mmHg}$ ).

* - reliably distinguishing values between groups $(\mathrm{p}<0.05)$.
Compliance with this principle made it possible to significantly reduce the volume of infusion therapy in the main group of patients and not prevail over daily needs. In the first postoperative day of observation, it was $37.6 \pm 2.7 \mathrm{ml} / \mathrm{kg}$, in the second $-16.8 \pm$ $1.6 \mathrm{ml} / \mathrm{kg}$ of body weight. A decrease in the volume of infusion is associated with the restoration of the transient function of the gastrointestinal tract, due to the preservation of normal transcapillary metabolism and the absence of edema of the interrstitial space zh$\mathrm{k}-\mathrm{t}$ and the transfer of patients to enteral nutrition from the second day of the postoperative period.

Investigating the functional state of the hemostasis system in patients of the clinical comparison group, in which the correction of hemorrhage was carried out by hypervolemic hemodilution, damage to the coagulation (secondary) link of the hemostasis system was revealed, which is confirmed by the dynamics of fibrinogen. At the initial normal values on the second day, it increased to $7.25 \pm 1.87 \mathrm{~g} / \mathrm{l}$. with the simultaneous shortening of the coagulation time of whole blood and the presence of fibrin degradation products (PDF), which indicates damage to the hemocoagulation link of the hemostasis system and the development of disseminated intravascular coagulation.

Taking into account that adequate surgical hemostasis is achieved on the operating table, and 4 hours after the injury, an effective biological hemostasis is formed [1,2,7,14,23], we, for the first time in medical practice, then in the USSR, introduced the method of early heparinization, which consisted in the use of nonfractionated heparin 6 hours after the completion of the operation at a dose of $100 \mathrm{U} / \mathrm{kg}$ of weight per day under laboratory control of the hemostasis system and the time of coagulation of whole blood (VSK), the norm of which is $3.5-4.5$ minutes. The use of heparin in the main group of patients made it possible to completely avoid the likelihood of hypercoagulation and thrombosis, as evidenced by the dynamics of coagulation of whole blood and the concentration of fibrinogen, which on the second day after the operation was $3.15 \pm 0.29 \mathrm{~g} / \mathrm{l}$, and R-graphic studies of the lungs did not reveal lung damage.

A simultaneous decrease in the concentration of fibrinogen, stable VSK against the background of the absence of PDF and lung damage indicates the controllability of secondary hemostasis, improvement of the rheological properties of the blood and the effectiveness of the method used to correct hemorrhage. 


\section{Extensions}

In 2000 - 2005, this method of correction of hypovolemia/hemorrhage was improved and supplemented with two techniques that made it possible to increase its safety and clinical effectiveness.

Preoperative blood sampling in the volume of donor (up to $10 \%$ BCC), which has undeniable advantages over similar, but voluminous, which are as follows:

- Does not require any replacement infusion, therefore, excludes possible hidden damage to the body, including the hemostasis system, since the volume of blood procurement is donor,

- Promotes early preoperative stimulation of erythropoiesis, which is manifested by the production of full-fledged erythrocytes already on the 8th day of the postoperative period, instead of 14-15 days,

- Reduces the volume of postoperative infusion,

- Forms a protective anti-ischemic effect,

- Excludes/reduces the use of donor blood components,

- Forms a tolerant adaptation strategy, accompanied by a decrease in oxygen consumption by the myocardium and the body as a whole.

Postoperative return of drainage blood with special systems «Handy Vac» firm «UnaMedical» also has positive qualities:

- Drainage system provides absolute safety of return of drainage component,

- The return of drainage contents virtually eliminates the need to use components of donor blood,

- According to the biochemical composition, the drainage component is similar to the venous blood of the patient, except for the presence of platelets in it, which, by their volume in this drainage fluid, do not have clinical significance,

- The return of the drainage component completely eliminates the need for the use of donor blood or its components.

In our practical work over the past 18 years, we have successfully used these drainage systems, and we have practically eliminated the need for the use of donor blood and its components.

\section{Results}

Analysis of transcapillary metabolism in patients elderly and senile age

\begin{tabular}{|l|c|c|c|c|}
\hline & $\begin{array}{c}\text { Single auto } \\
\text { blood } \\
\text { sampling } \\
\text { In = 32) }\end{array}$ & $\begin{array}{c}\text { Double auto } \\
\text { blood } \\
\text { sampling } \\
(\mathbf{n = 1 8 )}\end{array}$ & $\begin{array}{c}\text { Without } \\
\text { autoblea } \\
\text { fence } \\
(\mathbf{n}=\mathbf{1 2})\end{array}$ & P \\
\hline $\begin{array}{l}\text { Total } \\
\text { protein (g/l) }\end{array}$ & $\begin{array}{c}76,3 \\
(68,6 ; 78,1)\end{array}$ & $\begin{array}{c}53,3 \\
(58,8 ; 76,6)^{*}\end{array}$ & $\begin{array}{c}78,4(64,5 ; \\
80)\end{array}$ & 0,045 \\
\hline $\begin{array}{l}\text { CODE } \\
(\mathrm{mmHg})\end{array}$ & 29,1 & 22,1 & $29,9(24,3 ;$ & 0,026 \\
\hline
\end{tabular}

Table a

* - P $<0,05$ (Criteria Mann-Whitney).

Dynamics of electrocardiographic parameters in elderly and senile patients without hemapheresis

\begin{tabular}{|l|c|c|}
\hline $\begin{array}{l}\text { Index } \\
\text { (n= 12) }\end{array}$ & Originally & $\begin{array}{c}\text { 1 day after } \\
\text { surgery }\end{array}$ \\
\hline $\begin{array}{l}\text { Violation of repolarization } \\
\text { processes, \% }\end{array}$ & $50,0(6)$ & $75(8)^{*}$ \\
\hline Ventricular e/systoles, \% & $16,7(2)$ & $25(3)$ \\
\hline Atrial fibrillation/flutter, \% & $8,3(1)$ & $8,3(1)$ \\
\hline Myocardial ischemia, \% & $16,7(2)$ & $33,3(4)^{*}$ \\
\hline Myocardial infarction & 0 & $8,3(1)^{*}$ \\
\hline $\begin{array}{l}\text { First-time rhythm } \\
\text { disturbances }\end{array}$ & 0 & $16,7(2)^{*}$ \\
\hline
\end{tabular}

Table b

* $-\mathrm{P}<0,05$ (dependence criterion Chi-square).

Dynamics of electrocardiographic parameters in patients elderly and senile age with a single hemapheresis

\begin{tabular}{|l|c|c|c|}
\hline $\begin{array}{l}\text { Index } \\
\text { (n= 32) }\end{array}$ & Originally & $\begin{array}{c}\text { After the } \\
\text { auto-blood } \\
\text { fence }\end{array}$ & $\begin{array}{c}\text { Through } \\
\text { 1 day } \\
\text { after } \\
\text { surgery }\end{array}$ \\
\hline $\begin{array}{l}\text { Violation of } \\
\text { repolarization processes, } \\
\%\end{array}$ & $56,2(18)^{*}$ & $37,5(12)^{*}$ & $15,6(5)^{*}$ \\
\hline $\begin{array}{l}\text { Ventricular extrasystoles, } \\
\%\end{array}$ & $12,5(4)^{*}$ & $9,4(3)$ & $3,1(1)^{*}$ \\
\hline $\begin{array}{l}\text { Atrial fibrillation/flutter, } \\
\%\end{array}$ & $9,3(3)$ & $9,3(3)$ & $9,3(3)$ \\
\hline Myocardial ischemia, \% & $12,5(4)$ & $0^{*}$ & $0^{*}$ \\
\hline Myocardial infarction & 0 & 0 & 0 \\
\hline $\begin{array}{l}\text { First-time rhythm } \\
\text { disturbances }\end{array}$ & 0 & 0 & 0 \\
\hline
\end{tabular}

Table c

* - P $<0,05$ (dependence criterion Chi-square). 
Comparative analysis of hemostasis indicators in elderly and senile patients (Kruskal-Wallis ANOVA)

\begin{tabular}{|l|c|c|c|c|}
\hline Index & $\begin{array}{c}\text { Single auto blood } \\
\text { sampling } \\
\text { (n = 32) }\end{array}$ & $\begin{array}{c}\text { Double auto } \\
\text { blood } \\
\text { sampling } \\
\text { (n= 18) }\end{array}$ & $\begin{array}{c}\text { Without auto-blood } \\
\text { fence } \\
\text { (n= 12) }\end{array}$ & P \\
\hline Hematocrit, \% & $40(38 ; 44)$ & $36,5(28,5 ; 41,5)^{*}$ & $41(38 ; 46)$ & 0,037 \\
\hline Recalcification, s & $119(90 ; 138)$ & $\begin{array}{c}100 \\
(75,5 ; 112)^{*}\end{array}$ & $120(100 ; 132)$ & 0,03 \\
\hline Fibrinogen, d/l & $4,2(3,1 ; 4,8)$ & $3,9(3,3 ; 5)$ & $3,9(3,0 ; 5,0)$ & 0,062 \\
\hline Fibrinolysis, \% & $8,8(8 ; 15,1)$ & $10,5(7,8 ; 14,6)$ & $11,7(6,6 ; 14,4)$ & 0,078 \\
\hline Retraction, \% & $39(26,5 ; 47,9)^{*}$ & $\begin{array}{c}34,5(30,8 ; 44,5)^{*} \\
* *\end{array}$ & $30,5(26,4 ; 38,2)^{* * *}$ & 0,044 \\
\hline PTI, \% & $106,5(101 ; 109,6)$ & $100(91,7 ; 109,3)$ & $104(93,8 ; 108)$ & 0,093 \\
\hline APTT, s & $40,5(39 ; 41,5)^{*}$ & $33,4(30,3 ; 43,3)^{*}$ & $40,8(37,4 ; 44,5)$ & 0,024 \\
\hline RFMK & $4(3 ; 5,6)$ & $6(3 ; 12,5)^{*}$ & $3(0 ; 5)$ & 0,038 \\
\hline
\end{tabular}

Table d

* - P $<0,05$ (Criteria Mann-Whitney).

Comparative analysis of hemogram indicators in elderly and senile patients

\begin{tabular}{|l|c|c|c|c|}
\hline Index & $\begin{array}{c}\text { Single auto blood } \\
\text { sampling } \\
\text { (n= 32) }\end{array}$ & $\begin{array}{c}\text { Double auto blood } \\
\text { sampling } \\
\text { (n= 18) }\end{array}$ & $\begin{array}{c}\text { Double auto blood } \\
\text { sampling } \\
\text { (n= 18) }\end{array}$ & P \\
\hline $\begin{array}{l}\text { Hemorrhage } \\
\text { intraoperative, } \mathrm{ml}\end{array}$ & $370(300 ; 620)$ & $570(400 ; 1050)^{*}$ & $345(265 ; 680)$ & 0,038 \\
\hline $\begin{array}{l}\text { Hemorrhage } \\
\text { postoperative, } \mathrm{ml}\end{array}$ & $600(450 ; 850)$ & $650(385 ; 785)$ & $830(360 ; 1050)$ & 0,056 \\
\hline Erythrocytes, $\mathrm{x} 10^{12} / \mathrm{l}$ & $4,2(4 ; 2,2)$ & $3,4(2,8 ; 4,4)^{*}$ & $4,4(3,8 ; 4,6)$ & 0,012 \\
\hline JUICE, $\mu \mathrm{m}$ & $93,7(90 ; 103,2)^{*}$ & $102,2(93,5 ; 105,8)$ & $107,3(102 ; 114,5)$ & 0,034 \\
\hline SCG, g/l & $326,8(302,3 ; 348,7)^{*}$ & $316,2(304,2 ; 318)$ & $296,6(280 ; 312,2)$ & 0,028 \\
\hline Hemoglobin, $\mathrm{g} / \mathrm{l}$ & $133(130,5 ; 134)$ & $112(104 ; 132)^{*}$ & $142(136 ; 146)$ & 0,017 \\
\hline ESR, mm/h & $13(9,5 ; 17,6)$ & $20(12,5 ; 28,5)^{*}$ & $10(4 ; 22,5)$ & 0,038 \\
\hline Platelets, $\mathrm{x} 10^{9} / \mathrm{l}$ & $237,5(227 ; 244,8)$ & $245(232 ; 265)$ & $240,2(208,5 ; 296)$ & 0,098 \\
\hline Leukocytes, $\mathrm{x} 10^{9} / \mathrm{l}$ & $6,9(6,4 ; 8,5)$ & $10(7,9 ; 12,2)^{*}$ & $7,1(4,8 ; 12,0)$ & 0,049 \\
\hline
\end{tabular}

Table e

* $-P<0,05$ (criteria Mann-Whitney). 
Dynamics of some blood counts in patients young and middle-

aged in the perioperative period

\begin{tabular}{|l|c|c|c|c|}
\hline \multicolumn{2}{|c|}{ Group } & Lactate, mmol/l & Cortisol, nmol/l & Glucose, mol/l \\
\hline \multirow{2}{*}{$\begin{array}{l}\text { Before } \\
\text { surgery }\end{array}$} & $\begin{array}{l}\text { Clinical } \\
(\mathrm{n}=20)\end{array}$ & $2,76 \pm 0,5$ & $429(399 ; 512)$ & $5,1 \pm 1,0$ \\
\cline { 2 - 5 } \begin{tabular}{l} 
Operation \\
\cline { 2 - 5 }
\end{tabular} & Basic 1 ( $=17)$ & $1,9 \pm 0,2^{*}$ & $193(133 ; 512)^{*}$ & $4,6 \pm 1,1$ \\
\cline { 2 - 5 } & Basic 2group (n=18) & Basic group (n $=40)$ & $200(162 ; 448)^{*}$ & $5,0 \pm 0,8$ \\
\hline \multirow{2}{*}{$\begin{array}{l}\text { After } \\
\text { surgery } \\
\text { Operation }\end{array}$} & Clinical (n = 20) & $2,2 \pm 0,3$ & $489(459 ; 560)^{* *}$ & $5,8 \pm 1,5$ \\
\cline { 2 - 5 } & Basic 1 (n = 17) & $1,3 \pm 0,2^{*}$ & $369(280 ; 526)^{* *}$ & $5,0 \pm 0,8$ \\
\cline { 2 - 5 } & Basic 2 (n= 40) & $1,5 \pm 0,5^{*}$ & $493(262 ; 798)^{* *}$ & $5,5 \pm 0,5$ \\
\hline
\end{tabular}

Table f

* $-\mathrm{P}<0.001$ - reliably distinguishing values between groups (criteria Kruskal-Wallis);

** - P $<0.05$ - differences in the group. Control.

\section{Conclusion}

According to the results of the studies performed, in the main group of patients, significant clinical efficacy and an undeniable advantage were proved, which were as follows:

- $\quad$ All 41 operated patients who underwent hemihepatectomy were discharged with recovery, and 20 years of practical experience of this program confirmed its absolute effectiveness and safety.

- The total volume of infusion in the program of replenishment of blood loss, based on the normalization of MSW, decreased by 3.5 times and did not exceed the volume of pathological losses + daily needs of the body at the rate of $40 \mathrm{ml} / \mathrm{kg}$ per day.

- This method of correction of hypovolemia/hemorrhage avoids the development of SPON and ensures the safety of the transient function of gastrointestinal tract.

- The above noted, in turn, significantly reduces the volume of infusion therapy, allows patients to be transferred to the natural way of replenishing fluid and food ingredients, which is more effective and ensures a speedy recovery.

- $\quad$ The average time spent in PITiR of patients undergoing hemihepatektomy decreased from 5 to 1.5 days.

- The average residence time of trauma patients who have suffered blood loss of various volumes was also reduced to 1.3 days.

\section{Bibliography}

1. Bocharov SN. "Hepatic insufficiency after hemihepatectomy (pathogenesis, clinic, diagnosis, prevention and treatment)". Diss Dr. med. Sciences. SPb (1994): 134.

2. Bocharov SN., et al. "Method of replenishment of massive perioperative blood loss". Patent RU (2009).

3. Bocharov SN., et al. "The program of replenishment of massive blood loss. Traumatology and orthopedics of the third millennium". International Conference, Manchuria (2008): 27-28.

4. Bocharov SN., et al. "Tactics of intensive treatment of blood loss". Irkutsk (2007): 116.

5. Bocharov SN., et al. "System of anesthetic support for prosthetics of large joints”. Acta Biomedica Scientifica 6.18 (2017): 59-63.

6. Bocharov SN., et al. "Correction of intraoperative blood loss". Bulletin of the VSNC SB RAMS 6.1 (2002): 80-83.

7. Bocharov SN., et al. "Method of replenishment of blood loss". Patent RU (1999).

8. Bocharov SN and Teterina IP. "Correction of acute blood loss during operations on the organs of the hepato-pancreato-duodenal zone/Topical issues of reconstructive and reconstructive surgery". Irkutsk (1994): 267-269. 
9. Bocharov SN and Bocharova YuS. "Correction of hemorrhage. Collection of scientific articles on the results of the International Scientific Forum "Science and Innovations - Modern Concepts”. Moscow (2020): 92-97.

10. Bocharov SN., et al. "Clinical significance of transcapillary metabolism when performing infusion therapy". Polytrauma 2 (2021): 109-116.

11. Belousov AN. "Acute blood loss and criteria for its evaluation 77 electronic resource" (2018).

12. JE Morgan Jr., et al. "Clinical anesthesiology". T 2: per. s angl. / ed. A. A. Bunyatyan, A.M. Tseitlina-M.: Binom (2000): 365.

13. D Park and P Rowe. "Infusion therapy: per. with English. in a row. A.M. Ceitlina-M.: Binnom (2005): 136.

14. Zilber AP. “Clinical physiology in anesthesiology and resuscitation”. M Meditsina (1989): 256.

15. Ivanov EP. “Manual for gemmostaziology”. Minsk (1991): 300.

16. P Marino. "Intensive Therapy". per. s angl. dop. /gl. red. A.I. Martynov-M. Goetar Meditsina (1998): 640.

17. Solovyova IN. "Hematology and blood transfusion". Diss Dr. honey. Sciences. Moscow (2018): 280.

18. Sumin SA and Shapovalov KG. "Anesthesiology and resuscitation" 2 317-330.

19. Timofeev IV. "Pathology of treatment". A guide for doctors. SPb: Severo Zapad (1999): 534-578.

20. Usenko LV and Shifrin GA. "Intensive therapy for blood loss". Kiev (1990): 220.

21. Filimonov VI. "Guidelines for general and clinical physiology". M Medicichesnoe informatsionnoe agency (2002): 958.

22. A Kamkin and A Kamenskogo. "Fundamental and clinical physiology”. Edited by M Academia (2004): 1072.

23. All-Russian public organization "Federation of Anesthesiologists and Resuscitation Specialists". Protocol of resuscitation and intensive care for acute massive blood loss. Electronic access (2021).

24. Bartels K., et al. "Rational fluid management in today's ICU practice". Critical Care 17.1 (2013): S6.
25. Béchir M., et al. "Early fluid resuscitation with hyperoncotic hydroxyethyl starch 200/0.5 (10\%) in severe burn injury". Critical Care 14.3 (2010): R123.

26. Bentzer P., et al. "Will this hemodynamically unstable patient respond to a bolus of intravenous fluids?" JAMA 316.12 (2016): 1298-1309.

27. Caironi P., et al. "Albumin replacement in patients with severe sepsis or septic shock". New England Journal of Medicine 370.15 (2014): 1412-1421.

28. Fleck A., et al. "Increased vascular permeability: a major cause of hypoalbuminaemia in disease and injury". The Lancet 325.8432 (1985): 781-784.

29. Perel P., et al. "Colloids versus crystalloids for fluid resuscitation in critically ill patients". The Cochrane Library (2013).

30. Perner A., et al. "Hydroxyethyl starch 130/0.42 versus Ringer's acetate in severe sepsis". New England Journal of Medicine 367.2 (2012): 124-134.

31. Semler MW., et al. "Balanced crystalloids versus saline in critically ill adults". New England Journal of Medicine 378.9 (2018): 829-839.

32. Shaw AD., et al. "Major complications, mortality, and resource utilization after open abdominal surgery: 0.9\% saline compared to Plasma-Lyte". Annals of Surgery 255.5 (2012): 821829.

33. Van Der Linden P., et al. "Safety of modern starches used during surgery". Anesthesia and Analgesia 116.1 (2013): 35-48.

34. Zazzeron L., et al. "Role of albumin, starches and gelatins versus crystalloids in volume resuscitation of critically ill patients". Current Opinion in Critical Care 22.5 (2016): 428-436.

\section{Assets from publication with us}

- Prompt Acknowledgement after receiving the article

- Thorough Double blinded peer review

- Rapid Publication

- Issue of Publication Certificate

- High visibility of your Published work

Website: www.actascientific.com/

Submit Article: www.actascientific.com/submission.php

Email us: editor@actascientific.com

Contact us: +919182824667 